\title{
POST-ACIDIFICATION AND EVALUATION OF ANTHOCYANINS STABILITY AND ANTIOXIDANT ACTIVITY IN AÇAI FERMENTED MILK AND YOGURTS (Euterpe oleracea Mart.)
}

\author{
DANIELA CAVALCANTE DOS SANTOS CAMPOS², \\ LEANDRO TIMONI BUCHIDID CARMAGO NEVES ${ }^{3}$, ADRIANA FLACH ${ }^{4}$, \\ LUIZ ANTONIO MENDONÇA ALVES COSTA ${ }^{5}$, BEATRIZ OLIVEIRA DE SOUSA ${ }^{6}$
}

\begin{abstract}
This study evaluated the post-acidification, stability of anthocyanins and antioxidant activity in açai yogurts and fermented milks for 28 days of cold storage. For the determination of post-acidification and stability of the functional properties of açai yogurt (IA) and fermented milks (LFA), products stored at $4^{\circ} \mathrm{C}$ were evaluated on day 0 and every 7 days for $\mathrm{pH}$, titratable acidity in lactic acid, instrumental color, anthocyanins and antioxidant activity by the DPPH free radical method. Acidification of both food matrixes was more evident between days 0 and 7 of evaluation. IA presented reduction in parameter $\mathrm{L}^{*}$, while chromaticity $\mathrm{a} *$ and $\mathrm{b} *$ of IA and LFA increased as the Açai pulp content increased; however, considering the evaluation period, it was found increase in $L *$ and $b *$ relating to anthocyanin degradation. Anthocyanins, as well as the antioxidant activity of IA and LFA, showed an increase in their values as the pulp content increased, but their concentrations reduced at the end of the storage period. IA and LFA can be considered excellent sources of antioxidants, being alternative to individuals not used to the consumption of fruits and vegetables.
\end{abstract}

Index terms: Dairy products, functional foods, native fruits, Amazon.

\section{ESTUDO DE PÓS-ACIDIFICAÇÃO E AVALIAÇÃO DA ESTABILIDADE DE ANTOCIANINAS E ATIVIDADE ANTIOXIDANTE EM IOGURTES E LEITES FERMENTADOS DE AÇAÍ (Euterpe oleracea Mart.)}

\begin{abstract}
RESUMO - Neste trabalho foi avaliada a pós-acidificação, a estabilidade das antocianinas e da atividade antioxidante em iogurtes e leites fermentados de açaí durante 28 dias de armazenamento refrigerado. Para determinação da pós-acidificação, assim como da estabilidade das propriedades funcionais dos iogurtes (IA) e leites fermentados (LFA) de açaí, os produtos armazenados a $4{ }^{\circ} \mathrm{C}$, foram avaliados no dia 0 e a cada 7 dias, quanto ao $\mathrm{pH}$, acidez titulável em ácido lático, cor instrumental, antocianinas e atividade antioxidante pelo método do radical livre DPPH. A acidificação de ambas as matrizes alimentares foram mais evidentes entre os dias 0 e 7 de avaliação. Os IA apesentaram redução no parâmetro L*, enquanto que as cromaticidade a* e b* dos IA e LFA aumentaram seus valores, à medida que o teor de polpa de açaí foi aumentado, entretanto considerando o período de avaliação, verificou-se aumento de $\mathrm{L}^{*} \mathrm{e} \mathrm{b}^{*}$ relacionando-se as degradações nas antocianinas. As antocianinas, assim como a atividade antioxidante dos IA e LFA mostraram aumento em seus valores conforme os teores de polpa foram aumentados, porém reduziram suas concentrações ao fim do período de armazenamento. Os IA e LFA, podem ser considerados excelentes fontes de substâncias antioxidantes, sendo alternativa a indivíduos não habituados ao consumo de frutas e legumes.
\end{abstract}

Termos para indexação: Produtos lácteos, alimentos funcionais, frutos nativos, Amazônia.

\footnotetext{
1(Paper 106-16). Received August 15, 2016. Accepted November 11,2016.

${ }^{2}$ Tecnóloga Agroindustrial, Professora Dra. da Escola Agrotécnica da Universidade Federal de Roraima. E-mail: daniela.campos@ ufrr.br

${ }^{3}$ Engenheiro Agrônomo, Professor Dr. do Departamento de Fitotecnia, Universidade Federal de Roraima. E-mail: rapelbtu@hotmail.com ${ }^{4}$ Químico, Professora Dra. do Departamento de Química, Universidade Federal de Roraima. E-mail: aflach@gmail.com ${ }^{5}$ Químico, Professor Dr. do Departamento de Química, Universidade Federal de Roraima. E-mail: luizufrr@gmail.com ${ }^{6}$ Tecnóloga em Agroecologia, Universidade Federal de Roraima E-mail: beatrizagroecologia1@gmail.com.br
} 


\section{INTRODUCTION}

The relationship between ingestion of fruits and vegetables and decreased risk of developing various chronic diseases mediated by the action of free radicals is well established in literature. (AVELLO; SUWALSKY, 2006). Related to it, researchs on the positive effect of dietary intake of berry fruits on human health and performance has focused on exotic tropical red-black berries in the last few years (VASCONCELOS; GARCIA-DIAZ; JIMENEZ, SILVA, 2013).

The tropical region of South America produces a considerable amount of native and exotic fruits (VASCONCELOS et al., 2013), among tropical berry fruits, açai (Euterpe oleracea Mart.) has received special attention lately due to its high antioxidant activity and potential as a functional food or functional food ingrediente (KANG et al., 2010).

The high functional power of açai makes it a valuable food against several morbidities and mortalities associated with diseases that affect the circulatory system. Fruits are composed of unsaturated fatty acids (FA), which act preventing excessive LDL deposition on the cell walls, while purple pigments called anthocyanins, combat free radicals that are responsible for the LDL-cholesterol oxidation and decrease of HDL levels "good cholesterol" (OLIVEIRA et al., 2015).

Fermented milk products are a rich source of protein, calcium, phosphorus, vitamins and carbohydrates. The consumption of these products is related to the positive image of healthy and nutritious food, coupled with its sensory properties (FERREIRA et al, 2001). In the decade of 1960s, the addition of fruits to yogurt was aimed to mitigate the acid taste and increase the nutritional value of the product with vitami açains and bioactive compounds inherent to fruits (CAVALCANTE et al., 2009).

In addition to supplementation of dairy products with fruits, there is a new trend in this market, the use of probiotic microorganisms, which act as "biotechnological" or "therapeutic" agents, able to reduce post-acidification promoted by Lactobacillus bulgaricus, or promote beneficial effects in consumers (ANTUNES, 2001).

Regarding the shelf stability of these products, the post-acidification study is an important step because it reflects the metabolic behavior of microorganisms and is defined as the increase in acidity due to the continuous production of acids by lactic acid bacteria present in these products (LOURENS-HATTINGH; VILJOEN, 2001). However, the type of starter culture should be considered during the study, since post-acidification behaviors are distinct, for example, the low acidification promoted by probiotic bacteria such as Bifidobacterium spp. and Lactobacillus acidophilus in relation to Lactobacillus bulgaricus, justified by the low proteolytic rate promoted by these microorganisms (GOMES; MALCATA, 1999).

In this sense, the aim of this work was to study the post-acidification of yogurts and fermented milks added of different levels of açai pulp and evaluate their effects on the stability of anthocyanins and antioxidant activity during 28 days of cold storage.

\section{MATERIAL AND METHODS}

Obtaining Açai pulp - Açai pulp was acquired from a particular orchard located in the municipality of Boa Vista in the months of February and March 2014, totaling $5 \mathrm{~kg}$ referring to fruits present in three bunches. Fruits were selected considering quality criteria related to skin color (purple) and no visual damage and rot. For pulping, fruits were immersed in water at $50^{\circ} \mathrm{C}$ for 45 minutes, being subsequently weighted and added of water, the same water used in the immersion step at 1.5: $1(\mathrm{v} /$ w) water/fruit ratio. Thereafter, fruits were submitted to content removing device and pulp was wrapped in $200 \mathrm{~mL}$ plastic containers and pasteurized at $95^{\circ} \mathrm{C}$ for two minutes, cooled to reach $10^{\circ} \mathrm{C}$ and then frozen at $-18^{\circ} \mathrm{C}$ until time of production of fermented milks and yogurts.

Production of açai fermented milks and yogurts - Açai fermented milks and yogurts encoded as LFA and IA, respectively, were processed in Agricultural Products Technology Laboratory (LTPA)/EAgro using UHT milk (Ultra High Temperature) standardized to $3.0 \%$ fat, with the addition, $8.0 \%$ sugar, $4.0 \%$ skimmed milk powder and traditional and probiotic bacterial cultures. The processing of fermented milk used $0.08 \%$ probiotic cultures containing Streptococcus termophillus, Bifidobacterium BB-12 (BB-12) and Lactobacillus acidophilus (LA-5) present in Bio Rich ${ }^{\circledR}$ Chr Hansen yeast, incubated in oven with air circulation at temperature of $41 \pm 3{ }^{\circ} \mathrm{C}$ for 4 hours. Yogurt was prepared using $1.5 \%$ of traditional cultures containing Streptococcus termophillus and Lactobacillus bulgaricus available in Ricaferm YR03 yeast of Ricanata company, incubated in an oven with air circulation at temperature of $43 \pm 3^{\circ} \mathrm{C}$ for 4 hours. After cooling and 24-hour maturation period, açai pulps at concentrations of $5 \%, 10 \%$, $15 \%$ and $20 \%(\mathrm{w} / \mathrm{w})$ (BRASIL, 2007) were added. 
Fermented milk and fruit yogurts, about $25 \pm 2 \mathrm{~g}$, were placed in polyethylene terephthalate (PET) packages with oxygen permeability rate of $94 \mathrm{~cm} 3 /$ $\mathrm{m} 2$.day (FARIA, 2011) and capacity of $145 \mathrm{ml}$ and kept under refrigeration at temperature of $4 \pm 2^{\circ} \mathrm{C}$ for 28 days. In addition to fermented milk and yogurts added of fruit pulp, natural yogurts were separated and packaged, i.e., without pulp addition and under the same experimental conditions to serve as control treatment during post-acidification evaluation of test products.

Post-acidification studies - Conducted in yogurts and fermented milks at all pulp concentrations and in control treatments without pulp called LFA nat and IA nat. Fermented products were evaluated in triplicate on day 0 and every 7 days for a period of 28 days while $\mathrm{pH}$ and titratable acidity in lactic acid (g lactic acid $100 \mathrm{~g}^{-1}$ ) followed IAL (2008) recommendations.

Colorimetric analysis - Color evaluations were performed on day 0 and day 28 of storage by direct reading of reflectance of the rectangular coordinate system " $\mathrm{L} *$ " (brightness), "a*" (red and green intensity) and "b *" (yellow and blue intensity) using the CIELAB color scale and Spectrophotometer CM-5 (Konica Minolta).

Quantification of anthocyanins and DPPH antioxidant activity - Quantification of anthocyanins and antioxidant activity of fermented milks and yogurts with $5 \%, 10 \%, 15 \%$ and $20 \%(\mathrm{~m} / \mathrm{m})$ açai pulp content were performed on day 0 and every 7 days during 28 days of refrigerated storage at $4 \pm 1{ }^{\circ} \mathrm{C}$.

Determination of total anthocyanins was performed according to method described by Francis (1989), with some adjustments. For this measurement, solutions with concentration of $0.25 \mathrm{~g} \mathrm{ml}^{-1}$ for IA and LFA at all pulp levels, as well as for açai pulp were prepared. Solutions were homogenized with extraction solution $(1.5 \mathrm{~N} \mathrm{HCl}+85: 15$ Ethanol) and maintained at rest for 24 hours protected from light at room temperature. Absorbance was measured at $535 \mathrm{~nm}$ in UV-visible spectrophotometer (model UV - mini - 1240 - Shimadzu) using extraction solution as white. Results were obtained according to Francis (1989).

Antioxidant activity by DPPH assay: Determined by DPPH reduction (2,2-diphenyl1-picrylhydrazyl) by antioxidants present in the samples and quantified from a calibration curve using Trolox as default antioxidant (BRAND-WILLIANS et al., 1995; RUFINO et al., 2007) with adaptations. Stock solutions were prepared with concentration of $0.5 \mathrm{~g} \mathrm{ml}^{-1}$ for LFA and IA in all pulp concentrations, as well as for açai pulp. Aliquots were removed and added to the DPPH solution and kept at rest for 30 minutes protected from light, and thereafter, absorbance was measured at $515 \mathrm{~nm}$. Results were obtained using a calibration curve and expressed in $\mu \mathrm{Mol}$ Trolox equivalent ( $\mu \mathrm{Mol} \mathrm{TE})$.

Statistical analysis - Completely randomized design was adopted (CRD) in $2 \times 4 \times 5$ triple factorial ( 2 types of fermented products $\mathrm{x} 4$ pulp levels $\mathrm{x}$ 5 evaluation periods) and data were submitted to analysis of variance (ANOVA) followed by Tukey's test and regression analysis at 5\% significance level in computer program system for analysis of variance - SISVAR (FERREIRA, 2011 ). Pearson correlation $\left(\mathrm{R}^{2}\right)$ was performed to verify the influence of anthocyanins on the antioxidant activity of fermented milks and açai yogurts.

\section{RESULTS AND DISCUSSION}

\section{Post-acidification studies - Observing} the average $\mathrm{pH}$ values in the different pulp concentrations, it was found that the results obtained in LFA reduced significantly $(\mathrm{p} \leq 0.05)$ and linearly (Figure 1) as the pulp concentration increased, showing the effect of pulps on this variable. As for açai yogurt, $\mathrm{pH}$ variations did not follow linear decreasing pattern, and it was not possible to make adjustments on regression models up to the second degree. Evaluating types of fermented products, $\mathrm{pH}$ values were significantly $(\mathrm{p} \leq 0.05)$ higher in yogurts, which is probably related to the presence of Lactobacillus bulgaricus, since Bifidobacterium spp. and Lactobacillus acidophilus promoted more discrete post-acidification due to the low proteolytic rate promoted by these organisms (GOMES, MALCATA, 1999). Considering the pulp content $x$ fermented product $x$ days of evaluation interaction, significant reduction $(\mathrm{p} \leq 0.05)$ in $\mathrm{pH}$ values up to day 14 was observed in LFA and IA, with subsequent increase in days 21 and 28, adjusting in 2nd degree regression models for all pulp levels (Figure 2). Among the types of fermented products under study, it was found that IA had greater average $\mathrm{pH}$ decreases (12.3\%) during the 28-day trial period when compared to LFA $(10,8 \%)$, observing in both products, that the greatest reductions were found between days 0 and 7 . Oliveira e Damin (2003) studied different solids and sucrose contents in fermented milks and also found greater acidification effects between days 0 and 7 of evaluation, corroborating results presented in this study. Contrary to $\mathrm{pH}$, the titratable acidity results for all fermented products increased significantly $(\mathrm{p} \leq$ 0.05 ) and quadratically as the pulp content increased (Figure 3). Considering the pulp content $\mathrm{x}$ fermented 
product $\mathrm{x}$ days of evaluation interaction, significant increase $(\mathrm{P} \leq 0.05)$ in titratable acidity values in LFA and IA until day 21 followed by reduction on day 28 , adjusting in 2nd degree regression models for all pulp levels (Figure 4). Among the types of fermented product studied, it was found that IA showed average increases (40\%) in titratable acidity values higher than those observed in LFA (22\%) during the 28-day trial period; meoreover, the increase in pulp content led to greater increases in titratable acidity values during the study period, and IA $20 \%$ and LFA $20 \%$ were the most acidic at the end of the experimental period, showing possible positive influence of açai pulp for the development of traditional microorganisms and probiotics. These results agree with Barbosa (2007), who studied different percentages of peach pulp in fermented soy extract with Lactobacillus acidophilus and found increasing titratable acidity as the pulp content increased. However, Leite (2015) studied symbiotic yogurt with different açai pulp percentages and found no differences between titratable acidity values according to the pulp content. Regarding Instruction No. 46 of October 23, 2007 establishing the Identity and Quality Standard of Fermented Milk, all fermented products obtained in this work meet the legislation on minimum and maximum limits.

Colorimetric analysis - Considering the pulp contents, chromaticity parameters $\mathrm{L}^{*}, \mathrm{a}^{*}$ and $b^{*}$ showed reduction and significant increases, respectively (Figure 5), as the pulp content increased, indicating that the products became darker, agreeing with the results of Wallace e Giusti (2008). Considering days 0 and 28 of assessment of the average pulp levels in IA and LFA, there were increases in $\mathrm{L}^{*}$, showing discoloration, which is related to reduction in the anthocyanin content; however, the $\mathrm{a}^{*}$ values did not differ significantly ( $\mathrm{p} \leq$ 0.05 ) (Table 1 ). Regarding chromaticity $b^{*}$, there was an increase of this variable towards yellow, mainly in fermented products at $15 \%$ and $20 \%$ pulp content (Table 2). These results are consistent with studies by Ścibisz et al (2012) in blueberry probiotic yogurts, who related reduction in $\mathrm{L}^{*}$ parameter and increase in $b^{*}$ parameter during the storage of yogurt to the possible conversion of flavylium cation (colored) in colorless or yellowish forms.

Total anthocyanins - Regarding measurements made in the pulp and in fermented products, it was found that the anthocyanin content in the fermented product was different from levels found in the pulp, showing a drastic reduction in these components when added to the product (Table 3), which result is in agreement with Leite (2015). Reductions in the anthocyanin contents in
IA and LFA compared to the pulp can be related to the incorporation of oxygen during processing and pulp addition or to the tendency of these compounds to stabilize reactive oxygen species, since the high reaction power the hydroxyl group of anthocyanins with the radical makes it inactive (NIJVELDT, 2001), no longer being possible its quantification. It was observed that increasing the pulp content percentage significantly increased ( $p$ $\leq 0.05$ ) the anthocyanin concentrations in LFA and IA; however, the anthocyanin content was higher in LFA compared to IA. Ścibisz et al. (2012) reported that the microorganisms used in food production can generate enzymes causing hydrolysis of anthocyanin in less stable aglycone; therefore, the various microorganisms used in the production of IA and LFA may be related to differences in values. When considering the 28-day storage period, there is further loss of anthocyanins in LFA (50.4\%) over IA (40.6\%) (Figure 6), which is probably related to higher acidification observed in IA. According to Terci e Rossi (2002), anthocyanins are more stable at lower $\mathrm{pH}$ values, which explains the increased stability of these components in IA. Considering the assessment period between days 7 and 14, the highest average losses in pulp content with $28 \%$, and $7.7 \%$ reductions were verified for LFA and IA, coinciding with the period of increased acidification of these products and showing a probable relationship between postacidification and stability of anthocyanins. However, in addition to the effects of post-acidification, Gris et al. (2007) and Wallace e Giusti (2008) reported that the stability of anthocyanins in yogurt is also affected by storage, temperature, $\mathrm{pH}$ and content of other polyphenols and lipids in yogurt, and therefore further studies are needed to clarify the behavior of anthocyanins in this food matrix.

Antioxidant activity by DPPH method - Regarding the açai pulp, the antioxidant activity found in $100 \mathrm{~g}$ of pulp used in this study (Table 4) was below the results found by Schultz (2008) in fresh pulp $\left(9.2 \mu \mathrm{Mol} \mathrm{TE} \mathrm{g}^{-1}\right)$ and Kuskoski et al. (2006) $\left(6.9 \mu \mathrm{Mol} \mathrm{TE} \mathrm{g}^{-1}\right)$, being mainly related to its content of anthocyanins (LICHTENTHÄLER et al, 2005). Barbosa et al. (2016) conclude that antioxidant effects of açai may stem from the neutralization of free radicals, preventing their attack on other molecules, and/or from the modulation of enzymes involved in oxidative stress, showing the importance of this fruit to health benefitis. Considering fermented products, the behavior of the antioxidant activity coincided with the quantification of anthocyanins so that the antioxidant activity increased as the açai pulp content increased (Table 4), and in addition, the 
antioxidant activity observed in fermented products was lower than that obtained in açai pulp. However, if we compare the antioxidant activity of $100 \mathrm{~g}$ of yogurts and fermented milks evaluated in this study (Table 4) with the results of tropical fruit pulp such as blackberry $4.3 \mu \mathrm{mol} \mathrm{TE} \mathrm{g}^{-1}$, guava 5,9 $\mu \mathrm{mol} \mathrm{TE}$ $\mathrm{g}^{-1}$ (KUSKOSKI et al., 2006), and jaracatia 4.4 $\mu \mathrm{mol} \mathrm{TE} \mathrm{g}^{-1}$, araçá-boi $1.80 \mu \mathrm{mol} \mathrm{TE} \mathrm{g}^{-1}$ and passion fruit $0.80 \mu \mathrm{mol} \mathrm{TE} \mathrm{g}^{-1}$ (GENOVESE et al. 2008), it appears that yogurts and fermented milks can be compared with natural sources of antioxidants, being an excellent alternative for consumers who do not keep the habit of consuming fruits and vegetables, but on the other hand, consume industrialized and easily accessible products such as fermented products. The monitoring of the average antioxidant activity of IA and LFA showed at the end of the 28-day storage period, quadratic and linear activity losses of $61 \%$ and $53 \%$, respectively (Figure 7), agreeing with Leite (2015). Among the pulp contents, IA 20\% showed the greatest reduction in antioxidant activity throughout the study period, showing variations from
$7.18 \mu \mathrm{mol} \mathrm{TE} \mathrm{g}^{-1}$ to $2.05 \mu \mathrm{mol} \mathrm{TE} \mathrm{g} \mathrm{g}^{-1}$ between days 0 and 28 , reaching total loss of $71 \%$. For fermented milks, LFA 5\% showed the lowest antioxidant activity losses (44\%), while other products showed reductions around $55 \%$. In the period between days 0 and 7 of evaluation, more significant reductions in antioxidant activity were observed in IA and LFA of $39.6 \%$ and $31.1 \%$, respectively, concluding that the antioxidant activity of these products depends on the stability of anthocyanins. Regarding the influence of anthocyanins in the antioxidant activity of LFA and IA, there was a strong positive correlation (Table 5) between these variables, agreeing with Hassimotto et. al (2005), Kuskoski et al. (2006), who found a positive correlation between antioxidant activity and total polyphenol index and the content of anthocyanins in baguaçu and jambolão and Abe et al. (2007) in Vitis vinifera and Vitis labrusca cultivars and observed a positive association between contents of anthocyanins and antioxidant capacity by the DPPH free radicals scavenging method.

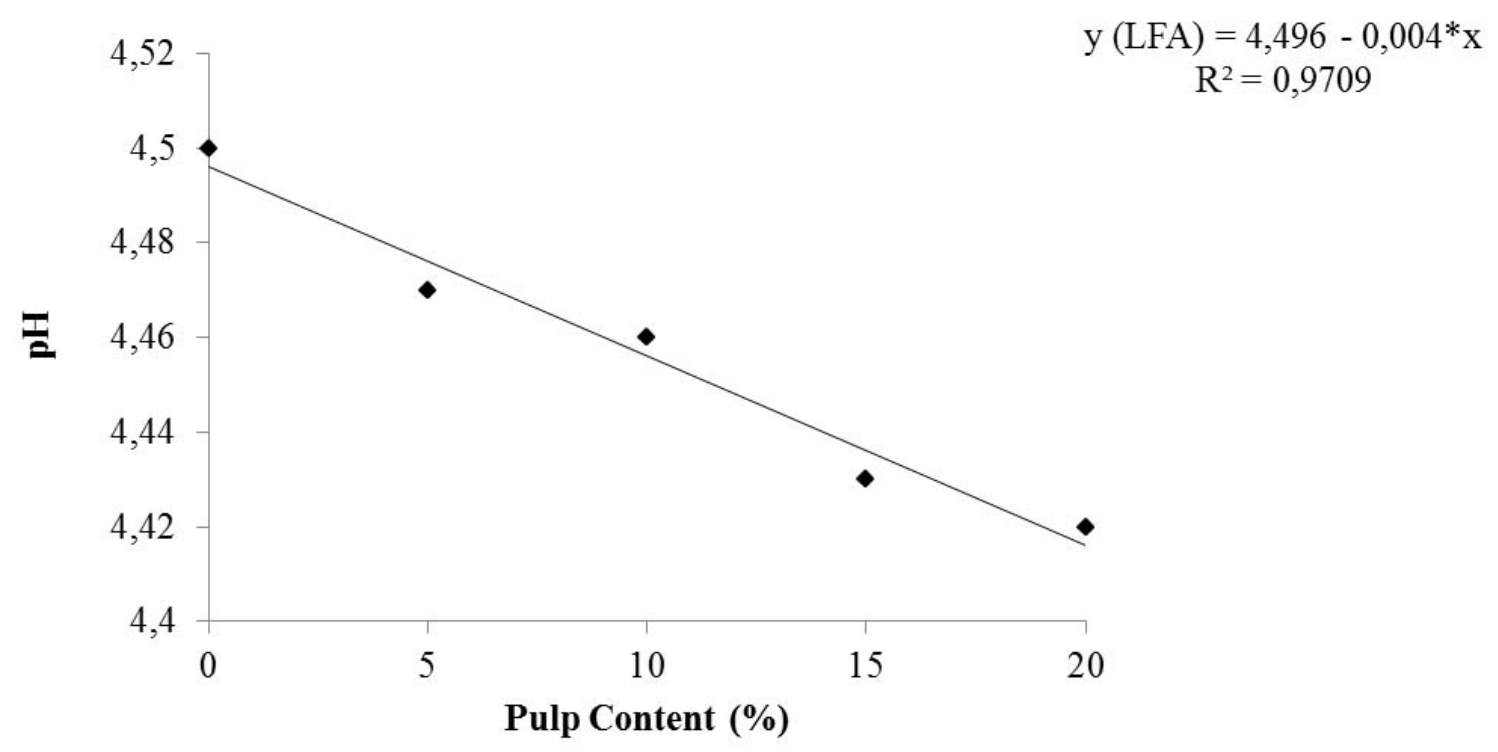

FIGURE 1 - Average $\mathrm{pH}$ values according to the açai pulp content in fermented milk. 


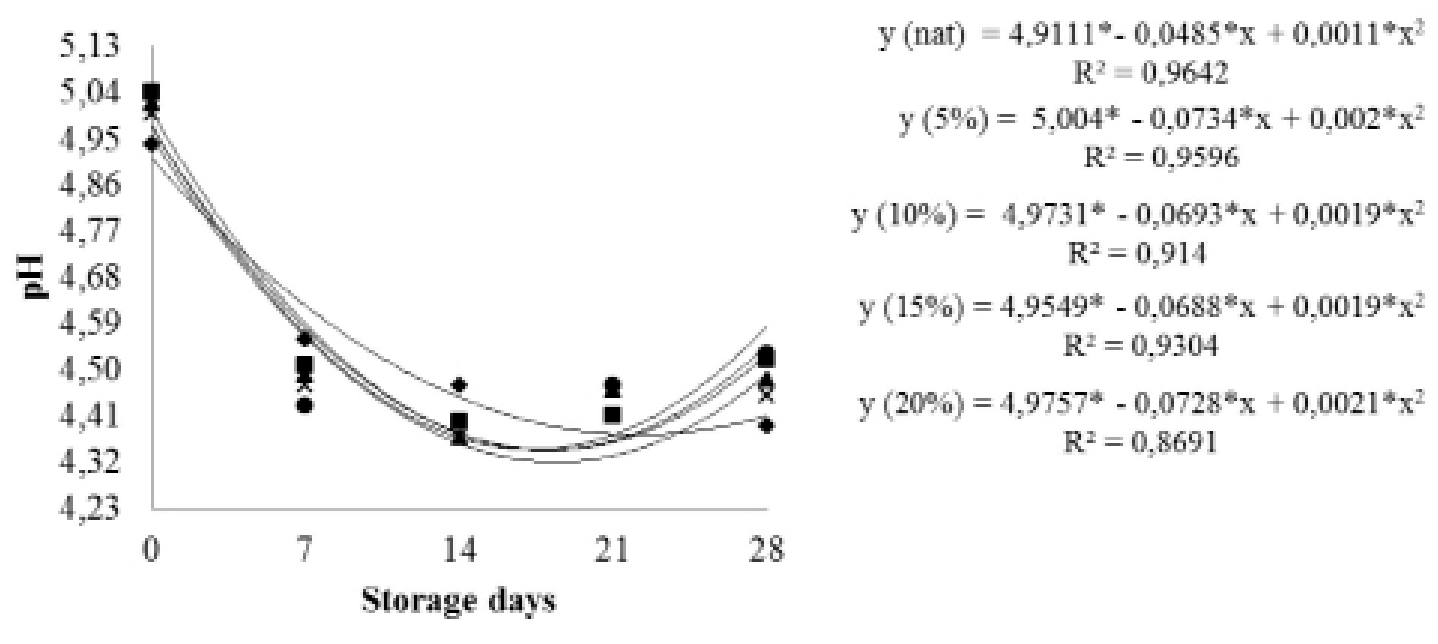

• IA NAT -IA $5 \%$ ^IA $10 \% \times$ IA $15 \% \bullet$ IA $20 \%$

(A)

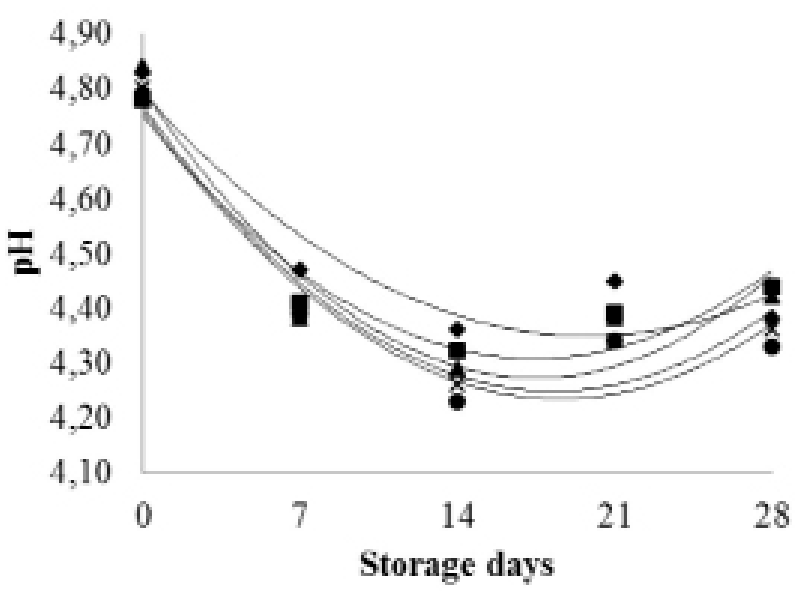

$$
\begin{array}{r}
y(\text { nat })=4,7934^{*}-0,045^{*} \mathrm{x}+0,0011^{*} \mathrm{x}^{2} \\
\mathrm{R}^{2}=0,8757 \\
\mathrm{y}(5 \%)=4,7509^{*}-0,0508^{*} \mathrm{x}+0,0015^{*} \mathrm{x}^{2} \\
\mathrm{R}^{2}=0,9301 \\
\mathrm{y}(10 \%)=4,7986^{*}-0,0602^{*} \mathrm{x}+0,0017^{*} \mathrm{x}^{2} \\
\mathrm{R}^{2}=0,9059 \\
\mathrm{y}(15 \%)=4,7689^{*}-0,057^{*} \mathrm{x}+0,0016^{*} \mathrm{x}^{2} \\
\mathrm{R}^{2}=0,9328 \\
\mathrm{y}(20 \%)=4,76^{*}=0,0567^{*} \mathrm{x}+0,0015^{*} \mathrm{x}^{2} \\
\mathrm{R}^{2}=0,9178
\end{array}
$$

$\bullet$ LFA NAT - LFA $5 \%$ \LFA $10 \% \times$ LFA $15 \% \bullet$ LFA $20 \%$

(B)

FIGURE 2 - pH values in açai yogurts $(A)$ and fermented milks $(B)$ during 28 days of cold storage. 


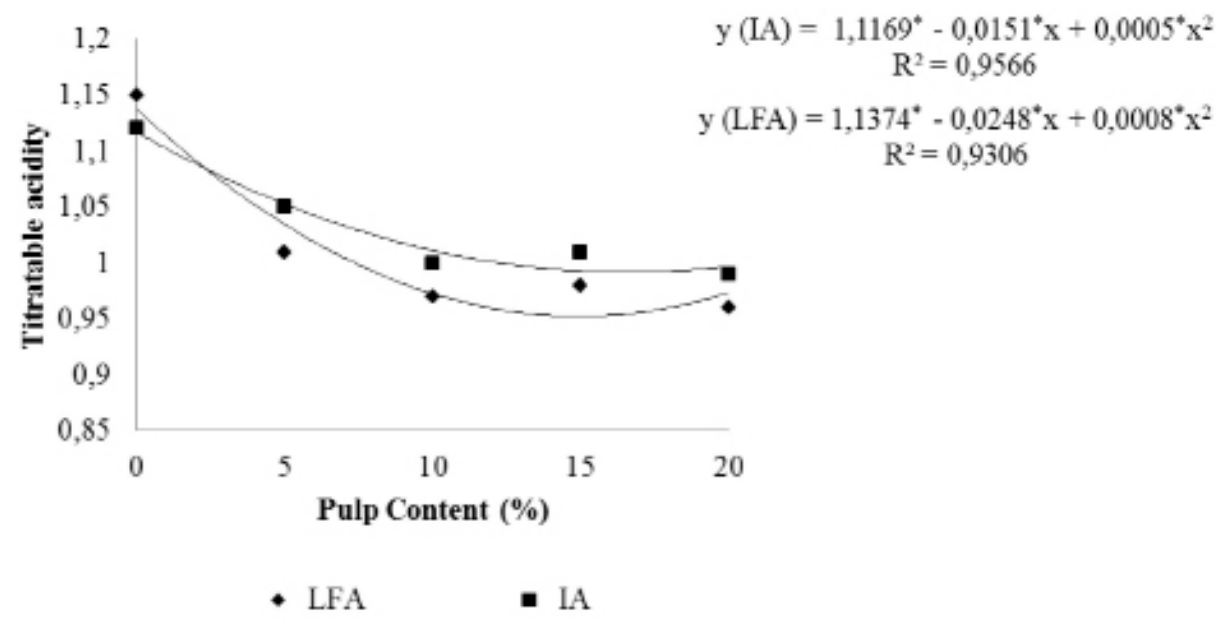

FIGURE 3 - Average titratable acidity values according to the açai pulp content in fermented milks and yogurts.

TABLE 1 - L* parameter behavior in açai yogurts and fermented milks on days 0 and 28 of evaluation.

\begin{tabular}{ccc}
\hline & \multicolumn{2}{c}{ Parameter luminosity $\left(\mathbf{L}^{*}\right)$} \\
\hline Type of fermented product & \multicolumn{2}{c}{ Days of evaluation } \\
& 0 & 28 \\
\cline { 2 - 3 } IA & $39,54 \mathrm{aA}$ & $43,34 \mathrm{aA}$ \\
LFA & $39,56 \mathrm{aA}$ & $41,01 \mathrm{aB}$ \\
\hline
\end{tabular}

Different small letters on the same line show significant difference $(\mathrm{p} \leq 0,05)$ at $5 \%$ probability.

Different capital letters in the same column show significant differences $(\mathrm{p} \leq 0,05)$ at $5 \%$ probability.

TABLE 2 - b* parameter behavior in açai yogurts and fermented milks with different pulp contents in days 0 and 28 of assessment.

\section{Chromaticity b*IA}

\begin{tabular}{ccccc}
\hline \multirow{2}{*}{ Pulp content (\%) } & \multicolumn{2}{c}{ Days of evaluation } & \multicolumn{2}{c}{ Days of evaluation } \\
& 0 & 28 & 0 & 28 \\
\cline { 2 - 5 } $\mathbf{5}$ & $2,97 \mathrm{bC}$ & $4,95 \mathrm{aC}$ & $3,12 \mathrm{bC}$ & $4,78 \mathrm{aC}$ \\
$\mathbf{1 0}$ & $3,97 \mathrm{bB}$ & $5,98 \mathrm{aB}$ & $4,57 \mathrm{bB}$ & $6,24 \mathrm{aB}$ \\
$\mathbf{1 5}$ & $4,51 \mathrm{bAB}$ & $7,44 \mathrm{aA}$ & $4,65 \mathrm{bB}$ & $5,67 \mathrm{aB}$ \\
$\mathbf{2 0}$ & $4,93 \mathrm{bA}$ & $6,83 \mathrm{aA}$ & $5,89 \mathrm{bA}$ & $7,13 \mathrm{aA}$ \\
\hline
\end{tabular}

Different small letters on the same line show significant difference $(\mathrm{p} \leq 0,05)$ at $5 \%$ probability.

Different capital letters in the same column show significant differences $(\mathrm{p} \leq 0,05)$ at $5 \%$ probability.

TABLE 3 - Average anthocyanin values $\left(\mathrm{mg}^{\left.100 \mathrm{~g}^{-1}\right)}\right.$ in fermented milks and yogurts with different pulp contents added and in açai pulp.

\begin{tabular}{ccc}
\hline Pulp content (\%) & LFA & IA \\
\cline { 2 - 3 } 5 & $6,98 \mathrm{aD}$ & $5,39 \mathrm{bD}$ \\
10 & $22,47 \mathrm{aC}$ & $17,77 \mathrm{bC}$ \\
15 & $46,23 \mathrm{aB}$ & $38,11 \mathrm{bB}$ \\
20 & $71,61 \mathrm{aA}$ & $63,14 \mathrm{bA}$ \\
\hline Açai Pulp & & 146,13
\end{tabular}

Different small letters on the same line show significant difference $(\mathrm{p} \leq 0,05)$ at $5 \%$ probability.

Different capital letters in the same column show significant differences $(\mathrm{p} \leq 0,05)$ at $5 \%$ probability. 


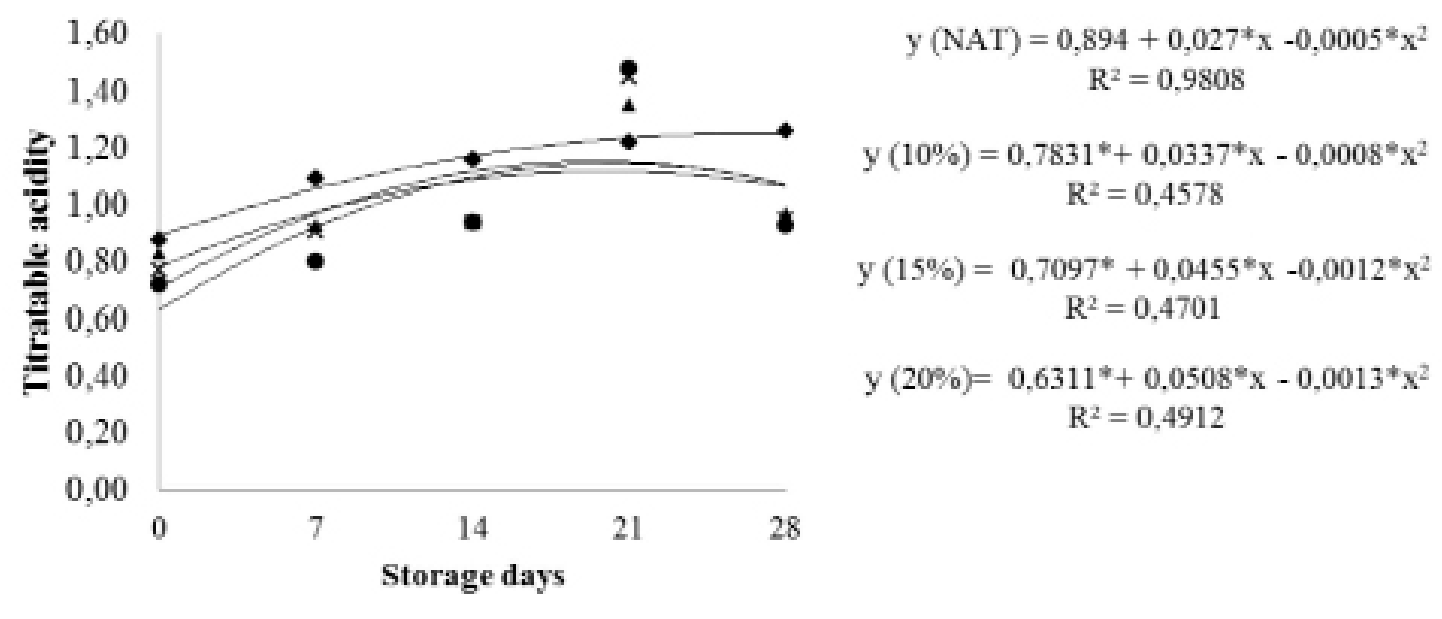

-IA NAT \IA $10 \% \times$ IA $15 \% \quad \bullet$ IA $20 \%$

(A)

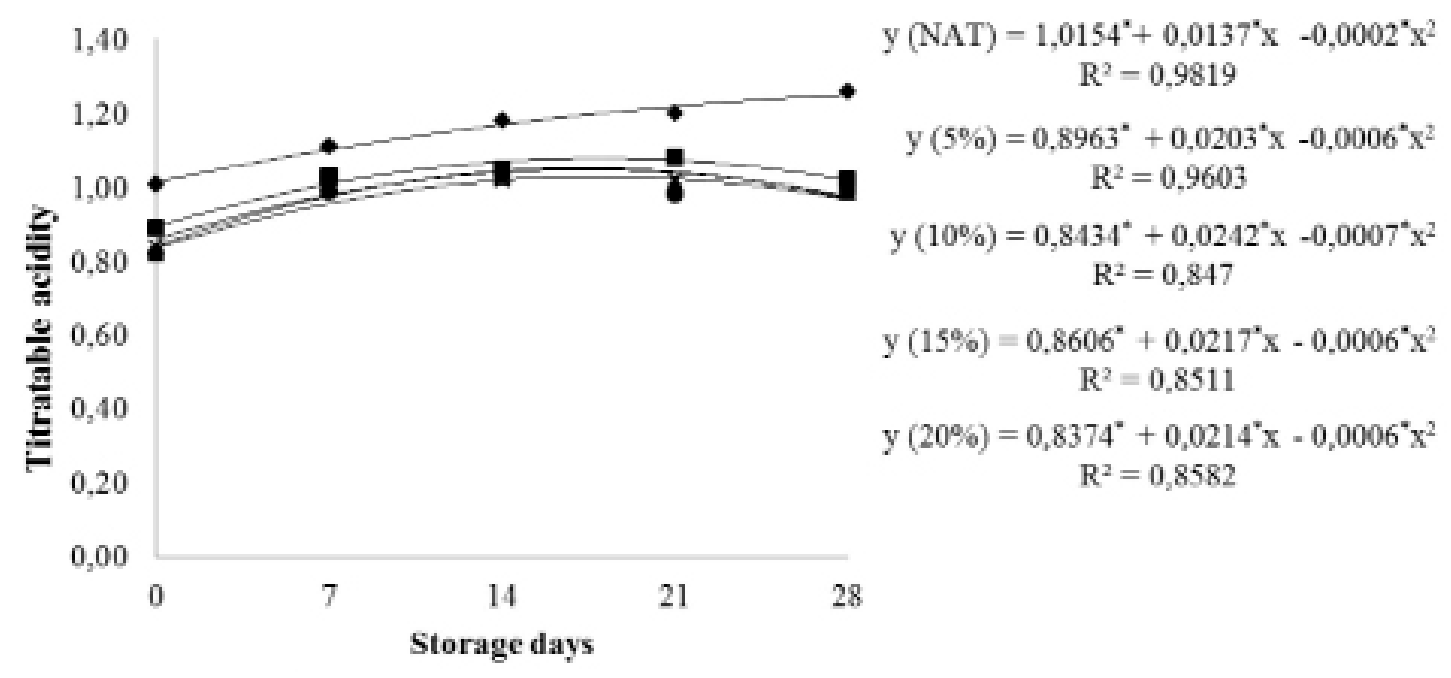

- LFA NAT - LFA $5 \%$ \LFA $10 \% \times$ LFA $15 \% \bullet$ LFA $20 \%$

(B)

FIGURE 4 - Titratable acidity values in açai yogurt (A) and fermented milks (B) during 28 days of cold storage. 


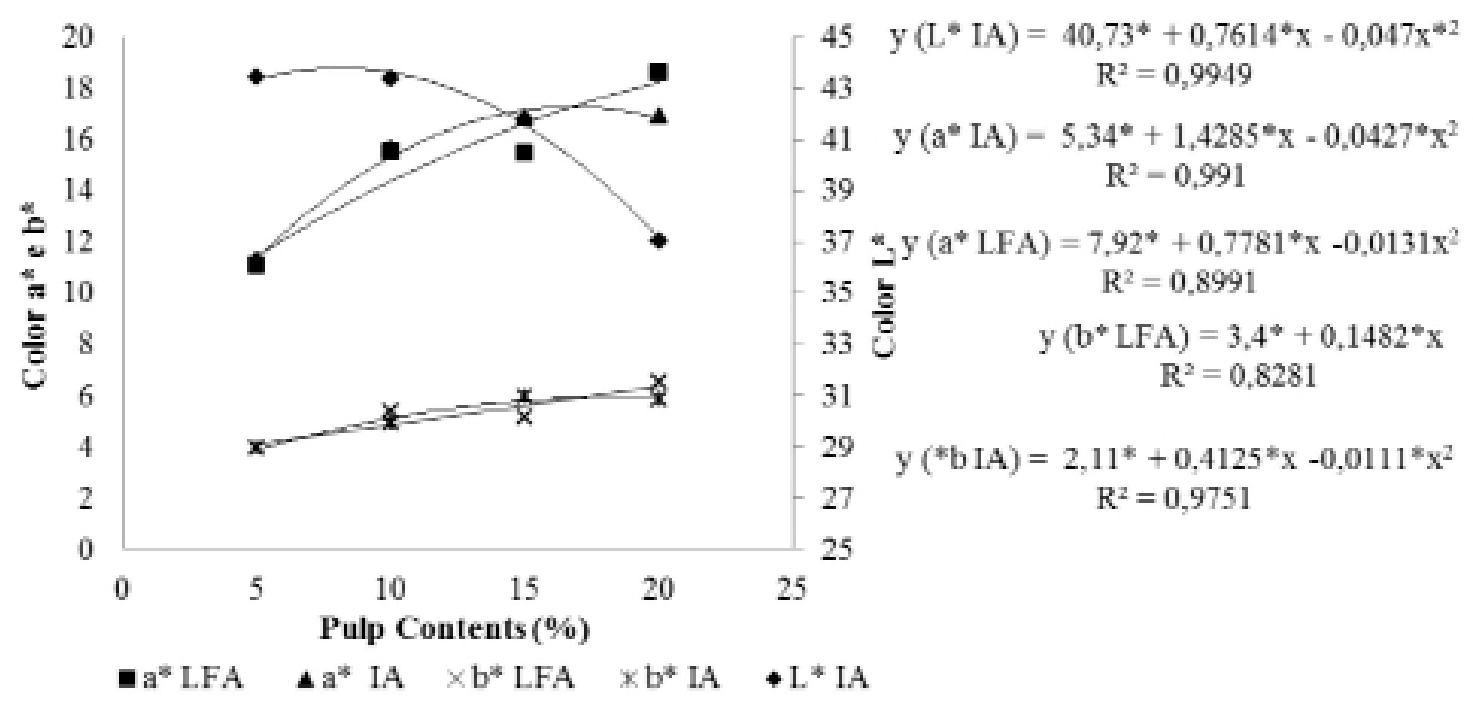

FIGURE 5 - Instrumental color parameters $\mathrm{L}^{*}, \mathrm{a}^{*}$ and $\mathrm{b}^{*}$ of açai fermented milks and yogurts in different pulp contents.

TABLE 4 - Average of antioxidant activity values in $\mu$ Mols TE $100 \mathrm{~g}^{-1}$ in açai fermented milks and yogurts with different pulp contents added and in açai pulp.

\begin{tabular}{ccc}
\hline Pulp content (\%) & LFA & IA \\
\cline { 2 - 3 } 5 & $2,80 \mathrm{aC}$ & $1,60 \mathrm{bD}$ \\
10 & $2,61 \mathrm{aC}$ & $2,35 \mathrm{bC}$ \\
15 & $3,61 \mathrm{aB}$ & $3,01 \mathrm{bB}$ \\
20 & $4,58 \mathrm{aA}$ & $3,68 \mathrm{bA}$ \\
\hline Açai Pulp $\left(\boldsymbol{\mu M o l ~ T E ~} \mathbf{1 0 0} \mathbf{~ g}^{-1}\right)$ & & 380,231 \\
\end{tabular}

Different small letters on the same line show significant difference $(\mathrm{p} \leq 0,05)$ at $5 \%$ probability.

Different capital letters in the same column show significant differences $(\mathrm{p} \leq 0,05)$ at $5 \%$ probability.

TABLE 5 - Correlation between anthocyanins and antioxidant activity by DPPH method in açai fermented milks and yogurts with different pulp contents during 28 days of storage.

\begin{tabular}{lcc}
\hline \multirow{2}{*}{ Variables in Correlation } & \multicolumn{3}{c}{ Correlation coefficients $\left(\mathbf{r}^{2}\right)$} \\
Anthocyanins/DPPH & LFA & IA \\
\cline { 2 - 3 } & 0.82 & 0.75 \\
\hline
\end{tabular}




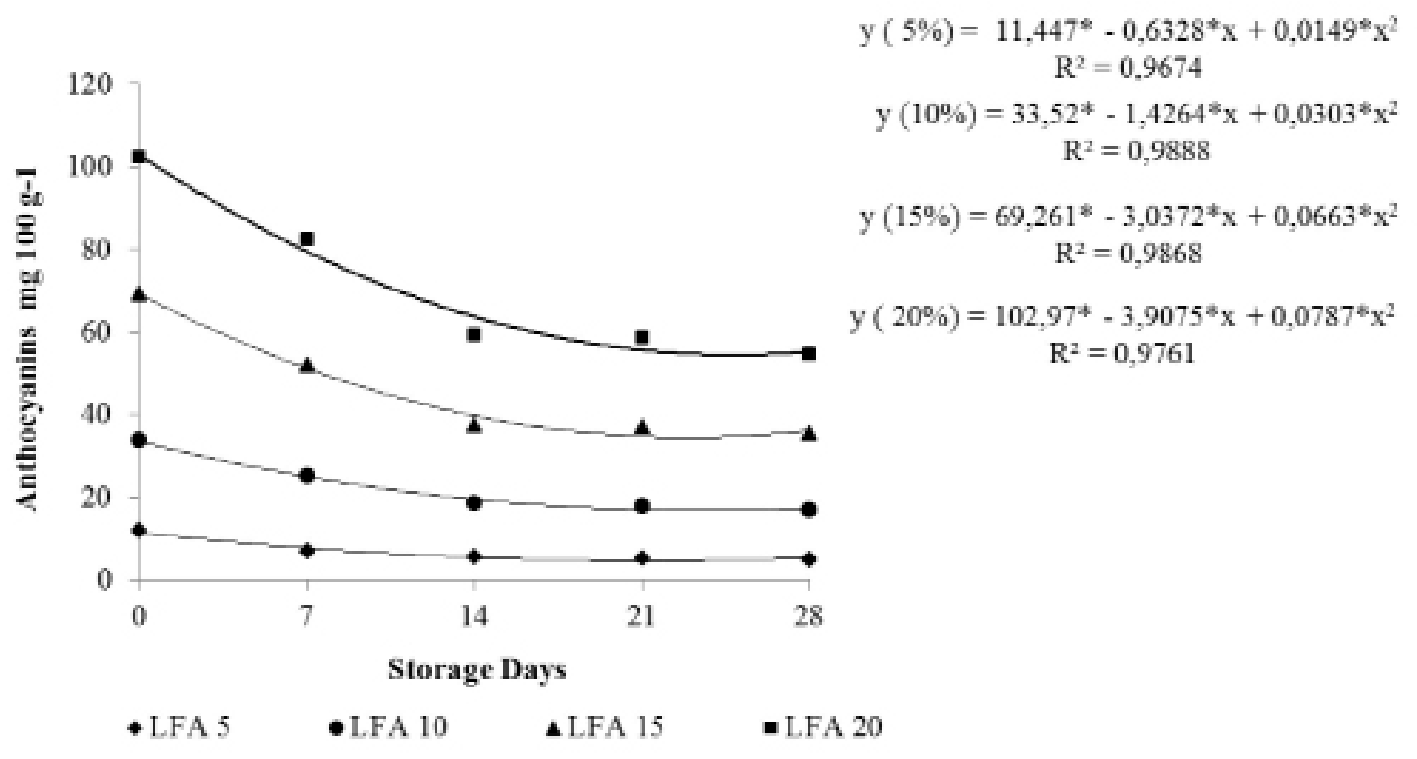

(A)

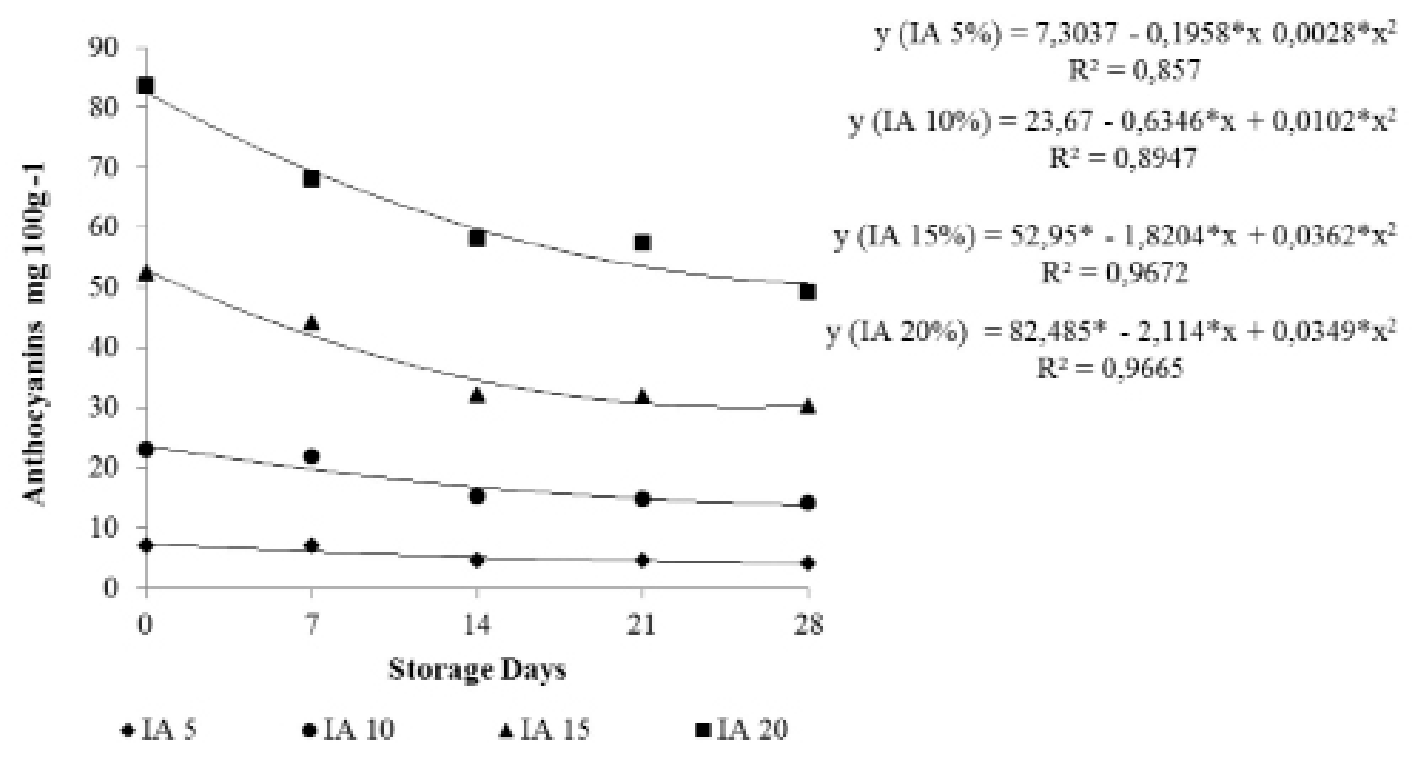

FIGURE 6 - Anthocyanins (100 $\left.\mathrm{mg} \mathrm{g}^{-1}\right)$ in açai yogurts (A) and fermented milks (B) during 28 days of storage . 


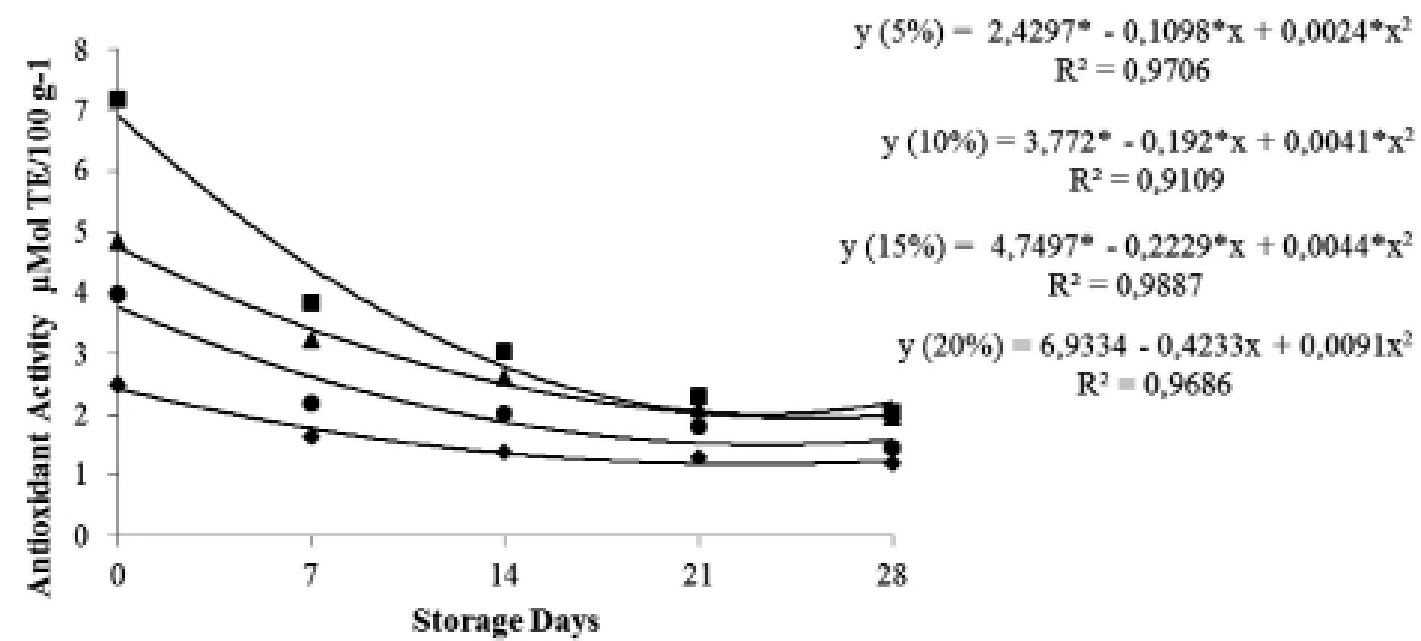

- IA 5

$\bullet$ IA 10

$\triangle$ IA 15

IA 20

(A)

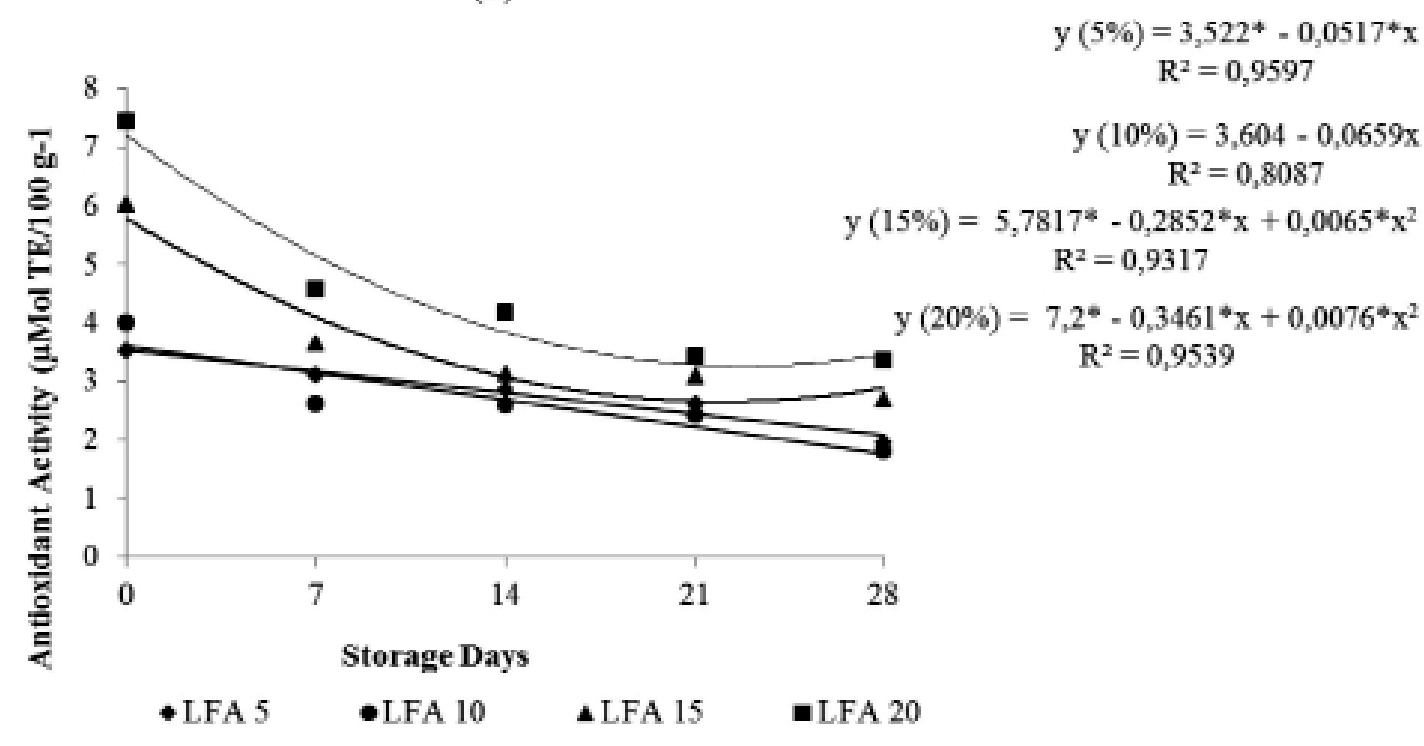

(B)

FIGURE 7 - Antioxidant activity in $\mu \mathrm{mol} \mathrm{TE} \mathrm{g}^{-1}$ in açai (A) fermented milks and $(B)$ yogurts during 28 days of storage. 


\section{CONCLUSIONS}

In the post-acidification, effect of the pulp content on $\mathrm{pH}$ and titratable acidity in lactic acid in both fermented products was observed, with the lowest values observed for IA. Acidifications were more evident between days 0 and 7, being higher in LFA and IA without pulp addition, which shows the negative effect of pulp on the metabolism of lactic acid bacteria. All fermented products were in line with legislation for titratable acidity. Colorimetric analysis of LFA and IA showed that parameters $\mathrm{L}^{*}$, $a^{*}$ and $b^{*}$ are influenced by the açai pulp content and shelf time. Color loss was observed after 28 days of storage, probably due to degradation of anthocyanins. Anthocyanins were proportionally influenced by the pulp content, and reduced by around $50 \%$ and $40 \%$ in LFA and IA at the end of 28 days of storage. IA showed more stable anthocyanins due greater acidification. The antioxidant activity of fermented products showed excellent correlation with anthocyanins and decreased with reduced concentration of these components.

\section{REFERENCES}

ABE, L. T; DA MOTA, R. V.; LAJOLO, F. M.; GENOVESE, M. I.; Compostos fenólicos e capacidade antioxidante de cultivares de uvas Vitis labrusca L. e Vitis vinifera L. Ciência e Tecnologia de Alimentos, Campinas, v.27, n.2, p.394-400, 2007.

ANTUNES, L. A. F. Microrganismos probióticos e alimentos funcionais. Indústria de Laticínios, São Paulo, v.6, n.34, p.30-34, 2001.

AVELLO, M.; SUWALSKY, M. Radicales libres, antioxidantes naturales y mecanismos de proteccion. Atena, Concepción, n.494, n.2, p.161-172, 2006.

BARBOSA, E. G..Prevalência de bactéria probiótica $L$. acidophilus - NCFM em extrato de soja fermentado e saborizado com sacarose e polpa de pêssego. 2007. 73 f. Dissertação (Mestrado em Ciência e Tecnologia Agroindustrial) - Universidade Federal do Rio Grande do Sul, Porto Alegre, 2007.

BARBOSA, P.O.; PALA, D.; SILVA, C.T.; SOUZA, M.O.; AMARAL, J.F.; VIEIRA, R.A.L.; FOLLY, G.A.F., VOLP, A.C.P.; FREITAS, R.N. Açai (Euterpe oleracea Mart.) pulp die tary intake improves cellular antioxidant enzymes and biomarkers of serum in healthy women. Nutrition, Burbank, v.32, n.6, p.674-680, 2016.
BRAND-WILLIAMS, W.; CUVELIER, M.E.; BERSET, C. Use of a free radical method to evaluate antioxidant activity. Food Science and Technology, London, v.28, n.1, p.25-30. 1995.

BRASIL. Instrução Normativa $n^{\circ} .46$, de 23 de outubro 2007. Regulamento técnico de identidade e qualidade de leites fermentados. Ministério da Agricultura e do Abastecimento. Secretaria de Defesa Agropecuária, Departamento de Inspeção de Produtos de Origem Animal. Diário Oficial da União, Brasília, DF, 24 out. 2007.

CAVALCANTE, J.M.; MORAIS, A.C.S.; RODRIGUES, M.C.P. Efeito da adição de amêndoas da castanha de caju nas propriedades sensoriais do iogurte adoçado com mel. Revista Brasileira de Tecnologia Agroindustrial, Ponta Grossa, v.3, n.1, p.1-14, 2009 .

FARIA, J.A.F.; WALTER, E.H.M.; CRUZ, A.G. Sistemas de embalagem para alimentos probióticos e prébióticos. In: SAAD S.M.I; CRUZ, A.G.; FARIA, J.A.F. Probióticos e prébióticos em alimentos: fundamentos e aplicações tecnológicas. São Paulo: Livraria Varela, 2011.

(CORRIGIR p.4 linha 21 de (FARIA, 2001) para (FARIA, 2011).

FERREIRA, C.L.L.F.; MALTA, H.L.; DIAS, A.S.; GUIMARÃES, A.; JACOB, F.E.; CUNHA, R.M.; CARELI, R.T.; PEREIRA, S.; FERREIRA, S.E.R. Verificação da qualidade físico-química e microbiológica de alguns iogurtes vendidos na região de Viçosa. Revista do Instituto de Laticínios Cândido Tostes, Juiz de Fora, v.56, n.321, p.152$158,2001$.

FERREIRA, D.F. Sisvar: a computer statistical analysis system. Ciência e Agrotecnologia, Lavras, v.35, p.1039-1042, 2011.

FRANCIS, F.J. Food Colorants: anthocyanins. Critical Reviews in Food Sciencie and Nutrition, Boca Raton, v.28, n.4, p.273-314, 1989.

GENOVESE, M.I.; PINTO, M.D.S.; GONCALVES, A.E.D.S. Bioactive compounds and antioxidant capacity of exotic fruits and commercial frozen pulps from Brazil. Food Science and Technology International, Thousand Oaks, v.14, n.3, p.207214, 2008. 
GOMES, A.M.P.; MALCATA, F.X. Bifidobacterium spp.and Lactobacillus acidophilus: biochemical, technological and therapeutical properties relevant for use as probiotics. Trends in Food Science and Technology, Amsterdam, v.10, n.4/5, p.139-157, 1999.

GRIS, E.F.; FERREIRA, E.A.; FALCA, L.D.; BORDIGNON-LUIZ, M.T. Influence of ferulic acid on stability of anthocyanins from Cabernet Sauvignon grapes in a model system and a yogurt system. International Journal of Food Science and Technology, Medford, v.42, n.8, p.992-998, 2007.

HASSIMOTTO, N.M.A.; GENOVESE, M.I.; LAJOLO, F.M. Antioxidant activity of dietary fruits, vegetables, and commercial frozen fruit pulps. Journal of Agricultural and Food Chemistry, Washington, v.53, n.8, p.2928-2935, 2005.

IAL - Instituto Adolfo Lutz. Métodos físicoquímicos para análise de alimentos. São Paulo, 2008. 1020 p.

KANG, J.; LI, Z. M.; WU, T.; JENSEN, G.S.; SCHAUSS, A.G.; WU, X. Anti-oxidant capacities of flavonoid compounds isolated from açai pulp (Euterpe oleracea Mart.). Food Chemistry, London, v.122, p.610-617, 2010.

KUSKOSKI, E.M.; ASUERO, A.G.; MORALES, M.T.; FETT, R. Frutos tropicais silvestres e polpas de frutas congeladas: atividade antioxidante, polifenóis e antocianinas. Ciência Rural, Santa Maria, v.36, n.4, p.1283-1287, 2006.

LEITE, S.T. Iogurte simbiótico de açaí (Euterpe edulis Mart.): caracterização físico-química e viabilidade de bactérias láticas e probiótica. 2015. 91f. Dissertação (Mestrado Ciência e Tecnologia de Alimentos) - Universidade Federal do Espirito Santo, Vitória, 2015.

LICHTENTHÄLER, R.; BELANDRINO, R.; RODRIGUES, J.G.S.M.; PAPAGIANNOPOULOS, M.; FABRICIUS, H.; MARX, F. Total oxidant scavenging capacities of Euterpe oleracea Mart. (Açai) fruits. International Journal of Food Sciences and Nutrition, Abingdon, v.56, n.1, p.5364, 2005.

LOURENS-HATTINGH, A.; VILJOEN, B.C. Growth and survival of a probiotic yeast in dairy products. Food Research International, Amsterdam, v.34, n.9, p.791-796, 2001.
NIJVELDT, R. J.; VAN NOOD, E.; VAN HOORN D. E.; BOELENS, P.G., VAN NORREN, K.; VAN LEEUWEN, P.A. Flavonoids: a review of probable mechanisms of action and potenctial applications. American Journal of Clinical Nutrition, New York, v.74, n.4, p.418-425, 2001.

OLIVEIRA, A.G.; COSTA, M.C.D.; ROCHA, S.M.B.M. Benefícios funcionais do açaí na prevenção das doenças cardiovasculares. Journal of Amazon Health Science, Rio Branco, v.1, n.1, p.1-10, 2015.

OLIVEIRA, M.N.; DAMIN, M.R. Efeito do teor de sólidos e da concentração de sacarose na acidificação, firmeza e viabilidade de bactérias do iogurte e probióticas em leite fermentado. Ciência e Tecnologia de Alimentos, Campinas, v.23, p.172176, 2003. Suplemento

RUFINO, M.D.M.; ALVES, R.E.; BRITO, E.S.; MORAIS, S.M.; SAMPAIO, C.G.; PEREZJIMENEZ, J.; SAURA-CALIXTO, F.D. Metodologia científica: determinação da atividade antioxidante total em frutas pela captura do radical livre DPPH. Fortaleza: Embrapa, 2007. (Comunicado Técnico, 127).

SCHULTZ, J. Compostos fenólicos, antocianinas e atividade antioxidante de açaís de Euterpe edulis Martius e Euterpe oleracea Martius submetidos a tratamentos para sua conservação. 2008. 51 f. Monografia (Trabalho de Conclusão de Curso em Agronomia) - Universidade Federal de Santa Catarina, Florianópolis, 2008.

ŚCIBISZ, I; ZIARNO, M; MITEKA, M.; ZAREBA, D. Effect of probiotic cultures on the stability of anthocyanins in blueberr y yoghurts. Food Science and Technology, Hoboken, v.49, n.2, p.208-212, 2012.

TERCI, D. B. L.; ROSSI, A. V.indicadores naturais de pH: usar papel ou solução? Química Nova, São Paulo, v.25 n.4, p.684-688, 2002. VASCONCELOS, A. G., GARCIA-DIAZ, D. F., JIMENEZ, P., SILVA, P.I. Bioactive compounds and health benefits of exotic tropical red-black berries. Journal of Functional Foods, London, v.5, n.2, p.539-549, 2013.

WALLACE, T. C.; GIUSTI, M. M. Determination of color, pigment, and phenolic stability in yogurt systems colored with nonacylated anthocyanins from Berberis boliviana L. as compared to other natural/ synthetic colorants. Journal of Food Science, Chicago, v.73, n.4, p.241-248, 2008. 